Ю.В. Думанський', А.М. Д’яченко², С.О. Решетняк², М.В. Фрейгофер²

\title{
Перший досвід використання суперселективної рентгенваскулярної емболізації та інтраопераційної флуоресцентної візуалізації у хірургічному лікуванні локалізованого раку нирки
}

\author{
${ }^{1}$ Інститут експериментальної патологї̈, онкології і радіобіології ім. Р.С. Кавецького НАН Украӥни, Київ \\ ${ }^{2}$ Комунальний заклад «Клінічний онкологічний диспансер», Дніпро \\ Одержано: 07.08.2019 \\ Прийнято до друку: 01.10.2019 \\ DOI: 10.32471 clinicaloncology.2663-466X.40.23130
}

\begin{abstract}
Частота виявлення локального раку нирки становить від 40 до 60\% у порівнянні із загальною кількістю виявлених новоутворень нирки. Тактика хірургічного лікування при локальному раку нирки, метод доступу, необхідність виконання теплової ішемії під час резекції, незважаючи на великий світовий досвід, залишаються остаточно не визначеними. Застосування сучасних методів діагностики - комп'ютерної томографії, ангіографії на передопераційному етапі - відіграє ключову роль у найточнішому визначенні локації пухлини в нирці, вивченні архітектоніки судин нирки, що дозволяє виконувати функціонально більш щадну операцію. Мета. Оптимізувати хірургічне лікування хворих з локальним раком нирки з використанням на передопераційному етапі суперселективної рентгенваскулярної емболізації та інтраопераційної флуоресцентної візуалізації в режимі інфрачервоної ділянки спектра з використанням індоціаніну зеленого (Indocyanine green). Матеріали і методи. Проводилося спостереження 2 хворих із локальним нирково-клітинним раком. Алгоритм обстеження та лікування був наступним: в обох випадках пухлини нирки було виявлено випадково під час профілактичної ультразвукової діагностики. У подальшому обом хворим виконано комп'ютерну томографію з внутрішньовенним посиленням для вивчення архітектоніки судин нирок в артеріальну фазу та визначення судини нирки, що підлягала емболізації. У якості наступного етапу лікування хворим було проведено ретроперитонеоскопічну резекцію нижнього полюсу нирки (ZERO ishemia) з визначенням кордонів резекції за допомогою інтраопераційної флуоресцентної візуалізації в режимі інфрачервоної ділянки спектра з використанням індоціаніну зеленого. Результати. 2 хворим на локальний нирково-клітинний рак виконано ретроперитонеоскопічну резекцію нирки (ZERO ishemia) з використанням інтраопераційної флуоресцентної візуалізації в режимі інфрачервоної ділянки спектра за допомогою індоціаніну зеленого. На передопераційному етапі хворим виконувалася суперселективна рентгенваскулярна емболізація. Під час операції та раннього післяопераційного періоду ускладнень не зареєстровано. Час операції становив в першому випадку 74 хв, у другому - 68 хв. Рівень інтраопераційної крововтрати в обох випадках склав близько 50 мл. Час знаходження в стаціонарі - 3 дні. В обох випадках при морфологічному дослідженні у хворих морфологічно верифікований світлоклітинний нирково-клітинний рак (pT1cNOMOROG2). Висновки. За попередніми даними, використання суперселективної рентгенваскулярної емболізації та інтраопераційної флуоресцентної візуалізації у хірургічному лікуванні локалізованого раку нирки у порівнянні зі стандартним методом хірургічного лікування має переваги.
\end{abstract}

Ключові слова: локалізований рак нирки, ретроперитонеоскопічна резекція, індоціанін зелений, суперселективна рентгенваскулярна емболізація судин нирки.

\section{ВСТУП}

Нирково-клітинний рак (НКР) становить 2-3\% серед усіх злоякісних пухлин. Загалом протягом останніх двох десятиріч відмічається щорічне підвищення частоти виникнення НКР як у Європі, та і у світі загалом. Частота захворюваності серед чоловіків у 1,5 раза вища, ніж серед жінок. Пік захворюваності припадає на вік 60-70 років [1]. Етіологічні фактори включають такі складові способу життя, як куріння, надмірна маса тіла, підвищений артеріальний тиск [2]. У 2017 р. загальна кількість нових випадків НКР в Україні становила 4776 випадків, при цьому від вказаної хвороби померло 1944 осіб. Незважаючи на покращення методів діагностики цієї патології, високу частоту $(56,6 \%)$ локального раку нирки, у $16,5 \%$ хворих серед виявлених у 2018 р. відмічали III, а у 21,9\% - IV стадію захворювання. Наведені дані свідчать про те, що підвищення ефективності лікування НКР лежить у площині використання, з одного боку, адекватних методів діагностики (ультразвукове дослідження (УЗД) та комп'ютерна томографія (КТ)), а з іншого - нових максимально сприятливих і радикальних методів корекції [3].

Систематичний огляд досліджень, присвячених застосуванню передопераційної суперселективної емболізації сегментарних ниркових судин при хірургічному лікуванні локального раку нирки, засвідчує можливість та доцільність використання цієї методики. Це дозволяє не виконувати традиційну інтраопераційну селективну або неселективну теплову ішемію, що супроводжується ризиком травматизації судин під час дисекції та негативно впливає на ниркову функцію у подальшому після припинення ішемії [4-11].

Аналіз літературних джерел показує, що натепер уже з'явилися дані щодо можливих переваг використання інтраопераційної флуоресцентної візуалізації в режимі інфрачервоної ділянки спектра, що впливає на ступінь інтраопераційної візуалізації та наочності кордонів при резекції нирки [12-16].

\section{ОБ'ЄКТ ТА МЕТОДИ ДОСЛІДЖЕННЯ}

Проведено аналіз хірургічного лікування 2 хворих із локальним НКР. Хворі були оперовані на базі К3 «Клінічний онкологічний диспансер» Дніпропетровської обласної ради».

Комплекс діагностичних досліджень був наступним: в обох випадках пухлини нирки були виявлено випадково під час профілактичного УЗД. У подальшому в обох випадках хворим виконано КТ з внутрішньовенним посиленням для вивчення архітектоніки судин нирок в артеріальну фазу. В обох випадках було діагностовано наявність пухлинного новоутворення ниж- 
нього полюсу нирки 5 см та 2,5 см, визначено нижньополярну артерію: в одному випадку - сегментарну, у іншому - субсегментарну, що живить частину нирки з пухлиною (рис. 1).

У якості наступного етапу обом хворим виконано рентгенваскулярну суперселективну емболізацію інтервенційним радіологом в одному випадку сегментарної у другому - субсегментарної артерії, що живить частину нирки з пухлиною. Для емболізації використовувалися спіралі Nester (Cook). Ускладнень під час та після радіологічної інтервенції не зареєстровано.

У подальшому, безпосередньо перед операцією, обом хворим повторно виконано КТ з внутрішньовенним контрастуванням. В обох випадках визначено повну селективну ішемію ділянки нирки, що підлягала резекції (рис. 2, 3).

Хворим під ендотрахеальним наркозом проведено ретроперитонеоскопічну резекцію нижнього полюсу нирки (ZERO ishemia) з визначенням кордонів резекції за допомогою інтраопераційної флуоресцентної візуалізації в режимі інфрачервоної ділянки спектра з використанням індоціаніну зеленого.

Аналіз ранніх післяопераційних ускладнень проводили відповідно до класифікації Клав'єна - Діндо [17]. Алгоритм діагностичних заходів та критерії морфологічної верифікації застосовували згідно з рекомендаціями National Comprehensive Cancer Network (NCCN), European Association of Urology (EAU).

\section{РЕЗУЛЬТАТИ}

Нами за останній час 2 хворим на локальний НКР виконано ретроперитонеоскопічну резекцію нирки (ZERO ishemia)

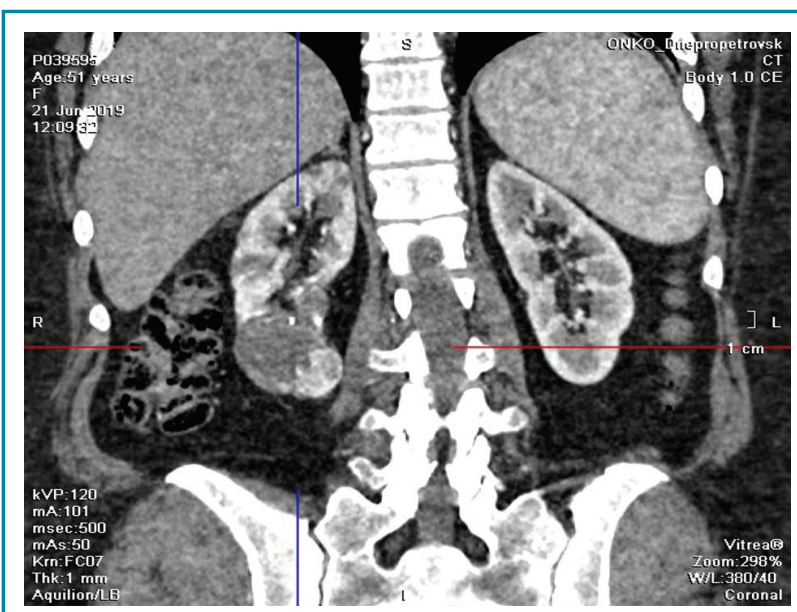

Рис. 1. КТ хворої Г. до хірургічного втручання. Діагноз рак нижнього полюсу правої нирки T1N0M0

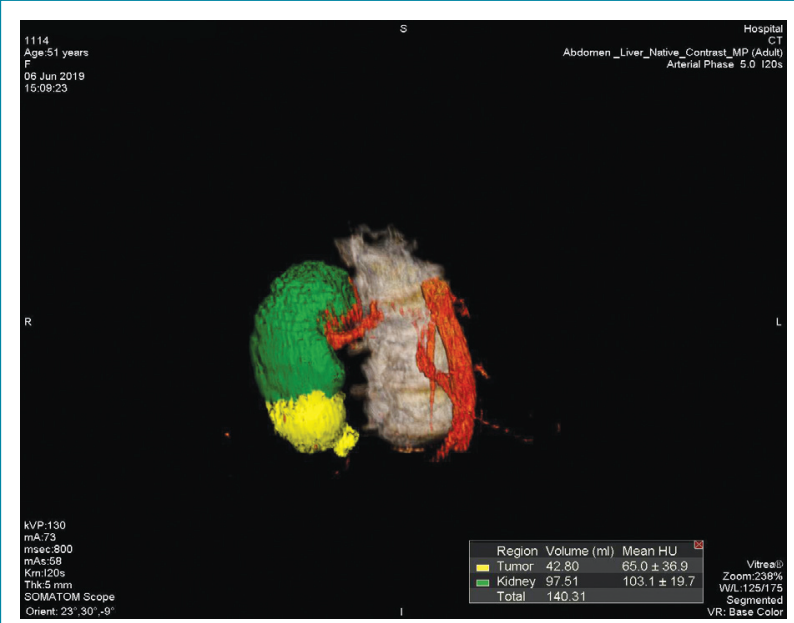

Рис. 2. КТ-реконструкція хворої Г. після виконаної селективної емболізації, до хірургічного втручання. Жовтим кольором виділена зона, яка планується для резекції

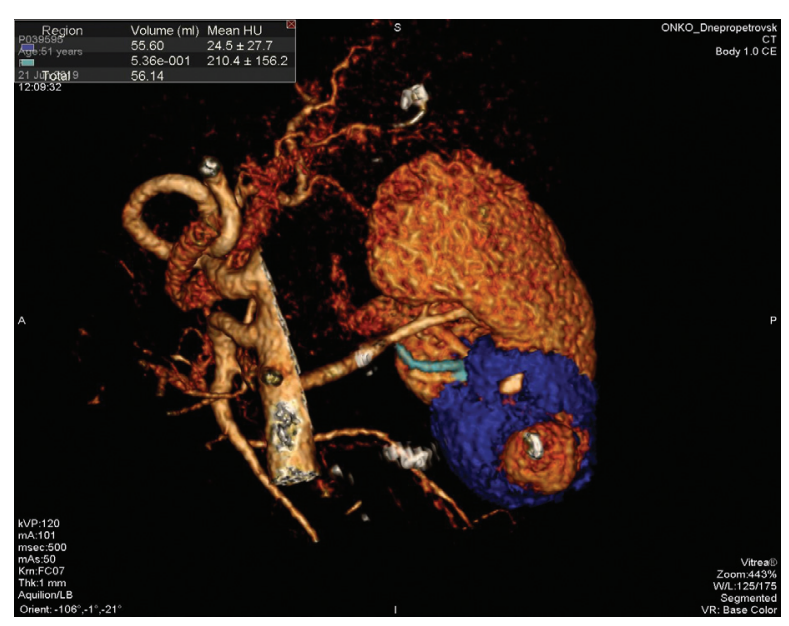

Рис. 3. КТ-реконструкція хворої Г. після виконаної селективної емболізації. Блакитним кольором виділена нижньосегментарна артерія, що живить зону нирки, яка підлягає резекції, синім - зона ішемії

з використанням інтраопераційної флуоресцентної візуалізації в режимі інфрачервоної ділянки спектра за допомогою індоціаніну зеленого. На передопераційному етапі хворим виконували суперселективну рентгенваскулярну емболізацію. В обох випадках хворі були жінками. Вік хворих був 66 та 51 рік.

Під час операції та раннього післяопераційного періоду ускладнень не зареєстровано. Час операції становив у першому випадку -74 хв, у другому -68 хв. Рівень інтраопераційної крововтрати в обох випадках становив близько 50 мл. Час знаходження в стаціонарі -3 дні. В обох випадках при морфологічному дослідженні у хворих морфологічно верифіковано світлоклітинний НKP (pT1cN0M0R0G2).

\section{ОБГОВОРЕННЯ}

Два наведених нами випадки з певною часткою достовірності дозволяють нам рекомендувати переваги цієї хірургічної методики та використання передопераційної рентгенваскулярної емболізації. При використанні описаного вище алгоритму лікування раку нирки застосування теплової ішемії зі всіма можливими ризиками та наслідками стає недоцільним. Невиправданою також видається інтраопераційна оцінка хірургічних кордонів з використанням сіtо-діагностики, беручи до уваги, що при такій методиці кордони резекції встановлюються заздалегідь, а не інтраопераційно, шо мінімізує наявність позитивних «хірургічних країв». Також рівень крововтрати при цій методиці мінімальний, що сприяє більш швидкому відновленню хворих у післяопераційний період. Слід також зазначити, що, враховуючи доступ (ретроперитонеоскопічний), у хворих після операції був практично відсутній больовий синдром, обидві хворі потребували введення нестероїдних протизапальних препаратів тільки в першу добу. Незважаючи на те що на результати лікування це ускладнення особливого впливу не чинить, слід зазначити, що практично відсутня можливість виникнення троакарних кил. При виконанні цього алгоритму хірургічного лікування хворих на локальний рак нирки у всіх випадках не відзначено жодних післяопераційних порушень моторики шлунково-кишкового тракту, які б потребували медикаментозної корекції.

\section{ВИСНОВКИ}

За попередніми даними, використання суперселективної рентгенваскулярної емболізації та інтраопераційної флуоресцентної візуалізації у хірургічному лікуванні локалізованого раку нирки у порівнянні зі стандартним методом хірургічного лікування має переваги. Автори цієї роботи вбачають перспективність продовження вивчення та впровадження запропоно- 
ваного алгоритму обстеження та лікування хворих на локальний рак нирки.

\section{СПИСОК ВИКОРИСТАНОЇ ЛІТЕРАТУРИ}

1. European Network of Cancer Registries. Eurocim version 4.0. European incidence database V2.3, 730 entity dictionary (2001), Lyon

2. Lipworth, L., Tarone, R. E., \& McLaughlin, J. K. (2006). The epidemiology of renal cell carcinoma. J Urol, 186(6), 2353-2358. doi: 10.1016/j.juro.2006.07.130.

3. Horan, J. J., Robertson, C. N., Choyke, P. L. Frank, J. A., Miller, D. L., Pass, H. I. \& Linehan, W. M. (1989). The detection of renal carcinoma extension into the renal vein and inferior vena cava: a prospective comparison of venocavagraphy and magnetic resonance imaging. J Urol, 142, 943-948. doi: 10.1016/s0022-5347(17)38948-6.

4. Jia, Z., Li, X. S., Zhang, C. J., Yang, K. W., Peng, D., Yang, J. H.,... Zhou, L. Q. (2017). The impact to operation safety of preoperative renal artery embolization for management of diameter $\geqslant 10 \mathrm{~cm}$ renal cell carcinoma. Zhonghua Wai Ke Za Zhi, 55(10), 738-741. doi: 10.3760/cma.j.issn.0529-5815.2017.10.004.

5. Provenza, G., Sparagna, A., Cunsolo, G. V., Tierno, S. M., Centanini, F., Bellotti, C., \& Mezzetti, G. (2013). Renal artery embolization in a gross kidney neoplasm. G Chir, 34(9-10), 263-266.

6. Heng-Li Shen, Shih-Chieh Chueh, Ming-Kuen Lai, Chen-Han Welfred Wu, Chun-Chieh Huang, Yuk-Ming Tsang,... Hong-Jeng Yu (2008). Balloon occlusion of the renal artery in laparoscopic partial nephectomy. Int J Urol, 15(11), 967-970. doi: 10.1111/j.1442-2042.2008.02158.x.

7. Lin, P. H., Terramani, T. T., Bush, R. L., Keane, T. E., Moore, R. G., \& Lumsden, A. B. (2003). Concomitant intraoperative renal artery embolization and resection of complex renal carcinoma. J Vascular Surgery, 38(3), 446-450. doi 10.1016/s0741-5214(03)00429-4.

8. Kalman, D., \& Varenhorst, E. (1999). The role of arterial embolization in renal cell carcinoma. Scand J Urol Nephrol, 33(3), 162-170. doi: 10.1080/003655999750015934.

9. Bakal, C. W., Cynamon, J., Lakritz, P. S., \& Sprayregen, S. (1993). Value of preoperative renal artery embolization in reducing blood transfusion requirements during nephrectomy for renal cell carcinoma. J Vasc Interv Radiol, 4(6), 727-731. doi: 10.1016/s1051-0443(93)71958-2

10. Popov, S. V., Guseinov, R. G., Martov, A. G., \& Muratov, T.M. (2017). Biomarkers of acute hypoxia-reoxygenation injury to nercycites during laparoscopic resection of renal parenchyma. Urologiia, 6, 120-125.

11. Volpe, A., Blute, M. L., \& Ficarra, V. (2015). Renal Ischemia and Function After Partial Nephrectomy: A Collaborative Review of the Literature. European Urology, 68(1), 61-74. doi: 10.1016/j.eururo.2015.01.025

12. Tobis, S., Knopf, J., Silvers, C., Yao, J., Rashid, H., Wu, G., \& Golijanin, D. (2011). Near infrared fluorescence imaging system for laparoscopic partial nephrectomy. J Urol, 25(6), 9606-9613. doi: 10.1016/j.juro.2011.02.2701

13. Ferroni, M. C., Sentell, K., \& Abaza, R. (2018). Current Role and Indications for the Use of Indocyanine Green in Robot-assisted Urologic Surgery. Eur Urol Focus, 4(5), 648-651. doi: 10.1016/j.euf.2018.07.009.

14. Hekman, M. C. H., Rijpkema, M., Langenhuijsen, J. F., Boerman, O. C., Oosterwijk, E., \& Mulders, P. F. A. (2018). Intraoperative Imaging Techniques to Support Complete Tumor Resection in Partial Nephrectomy. Eur Urol Focus, 4(6), 960-968. doi: 10.1016/j.euf.2017.04.008

15. Bjurlin, M. A., McClintock, T. R., \& Stifelman, M. D. (2015). Near-infrared fluorescence imaging with intraoperative administration of indocyanine green for robotic partial nephrectomy. Curr Urol Rep, 16(4), 20. doi: 10.1007/s11934-015-0495-9.

16. Mitsui, Y., Shiina, H., Arichi, N., Hiraoka, T., Inoue, S., Sumura, M.,... Igawa, M. (2012). Indocyanine green (ICG)-based fluorescence navigation system for discrimination of kidney cancer from normal parenchyma: application during partial nephrectomy. Int of kidney cancer from normal parenchyma: application during part
Urol Nephrol, 44(3), 753-759. doi: 10.1007/s11255-011-0120-x.

17. Dindo, D., Demartines, N., \& Clavien, P. A. (2004). Classification of surgical complications: a new proposal with evaluation in a cohort of 6336 patients and results of a survey. Ann Surg, 240(2), 205-213. doi: 10.1097/01.sla.0000133083.54934.ae.

Первый опыт использования суперселективной рентгенваскулярной эмболизации

и интраоперационной флуоресцентной

визуализации в хирургическом лечении

локального рака почки

Ю.В. Думанский ${ }^{1}$ А.М. Дьяченко ${ }^{2}$, С.А. Решетняк ${ }^{2}$, М.В. Фрейгофер 'Институт экспериментальной патологии, онкологии и радиобиологии им. Р.Е. Кавецкого НАН Украины, Киев ${ }^{2}$ КУ “Клинический онкологический диспансер”, Днепр

Резюме. Частота определения локального рака почки составляет от 40 до $60 \%$ в сравнении с общим количеством впервые выявленных новообразований почки. Тактика хирургического лечения при локальном раке почки, метод доступа, необходимость выполнения тепловой ишемии во время резекции, несмотря на большой мировой опыт, остаются окончательно не определенными. Применение современных методов диагностики - компьютерной томографии, ангиографии на предоперационном этапе играет ключевую роль в наиболее точном определении локации опухоли в почке, изучении архитектоники сосудов почки, что позволяет выполнять функционально более щадящую операцию. Цель. Оптимизировать хирургическое лечение пациентов с локальным раком почки с использованием на предоперационном этапе суперселективной рентгенваскулярной эмболизации и интраоперационной флуоресцентной визуализации в режиме инфракрасной области спектра с использованием индоцианина зеленого
(Indocyanine green). Материалы и методы. Проводилось наблюдение двух пациентов с локальным почечно-клеточным раком. Алгоритм исследования и лечение были следующими: в обоих случаях опухоли почки были выявлены случайно во время профилактической ультразвуковой диагностики. В дальнейшем обоим пациентам выполнена компьютерная томография с внутривенным усилением для изучения архитектоники сосудов почки в артериальную фазу и определения сосудов почки, которые подлежали эмболизации. В качестве следующего этапа лечения пациентам была проведена ретроперитонеоскопическая резекция нижнего полюса почки (ZERO ishemia) с определением границ резекции при помощи интраоперационной флуоресцентной визуализации в режиме инфракрасного участка спектра с использованием индоцианина зеленого. Результаты. 2 больным с локальным почечно-клеточным раком выполнена ретроперитонеоскопическая резекция почки (ZERO ishemia) с использованием интраоперационной флуоресцентной визуализации в режиме инфракрасного участка спектра при помощи индоцианина зеленого. На предоперационном этапе больным выполняли суперселективную рентгенваскулярную эмболизацию. Во время операции и раннего послеоперационного периода осложнений не зарегистрировано. Время операции составило в первом случае 74 мин, во втором - 68 мин. Уровень интраоперационной кровопотери в обоих случаях составил около 50 мл. Время нахождения в стационаре - 3 дня. В обоих случаях при морфологическом исследовании у больных морфологически верифицирован светлоклеточный почечно-клеточный рак (pT1cN0M0R0G2). Выводы. По предварительным данным, использование суперселективной рентгенваскулярной эмболизации и интраоперационной флуоресцентной визуализации в хирургическом лечении локализованного рака почки в сравнении со стандартным методом хирургического лечения имеет преимущества.

Ключевые слова: локализованный рак почки, ретроперитонеоскопическая резекция, индоцианин зеленый, суперселективная рентгенваскулярная эмболизация сосудов почки.

The first experience of using super-selective

$\mathrm{X}$-ray vascular embolization and intraoperative

fluorescence imaging in the surgical treatment of localized kidney cancer

U.V. Dumanskiy ${ }^{1}$, A.M. Diachenko ${ }^{2}$, S.A. Reshetniak ${ }^{2}$, M.V. Freigofer ${ }^{2}$ ${ }^{1}$ R.E. Kavetsky Institute of Experimental Pathology, Oncology and Radiobiology, NAS of Ukraine, Kyiv ${ }^{2}$ Dnipro Regional Oncological Centre

Summary. The incidence of local cancer of the kidney is from 40 to $60 \%$ in comparison with the total number of newly diagnosed kidney cancer. The tactics of surgical treatment for local cancer of the kidney, the access method, the need for heat ischemia during resection, despite extensive international experience, remain completely undefined. The use of modern diagnostic methods - computed tomography, preoperative angiography - play a key role in accurately determining the location of the tumor in the kidney, studying the architecture of the kidney vessels, which allows you to perform a functionally sparing operation. Objective. Optimize surgical treatment of patients with localized kidney cancer by using superselective X-ray vascular embolization and intraoperative fluorescence imaging in the infrared spectral mode using Indocyanine green at the preoperative stage. Materials and methods. Two patients with localized kidney cancer. The algorithm and treatment were as follows: in all cases, kidney tumors were identified by chance during prophylactic ultrasound diagnostics. Subsequently, patients underwent computed tomography with intravenous amplification to study the architectonics of the renal vessels during the arterial phase and the determination of the renal vessels that were to be embolized. As the next step in treatment of patients, retroperitoneoscopic 


\section{Оригінальні статті / Original Articles}

resection of the lower pole of the kidney (ZERO ishemia) was carried out to determine the boundaries of the resection using intraoperative fluorescence imaging in the infrared spectrum using indocyanin green (Indocyanine green). Results. 2 patients with local renal cell carcinoma performed retroperitoneoscopic resection of the kidney (ZERO ishemia) using intraoperative fluorescence imaging in mode of the infrared region of the spectrum using indocyanin green. In the preoperative stage, patients underwent superselective radiovascular embolization. During surgery and the early postoperative period of complications not registered. The operation time was in the first case of $74 \mathrm{~min}$, in the second $-68 \mathrm{~min}$. The level of intraoperative blood loss in both cases was about $50 \mathrm{ml}$. Hospital stay is 3 days. In both cases at morphological study in patients morphologically verified clear cell renal cell carcinoma (pT1cN0M0R0G2). Conclusions. According to preliminary data, the use of super-selective X-ray vascular embolization and intraoperative fluorescence imaging in the surgical treatment of localized kidney cancer in comparison with the standard method of surgical treatment has advantages.

Key words: localized kidney cancer, retroperitoneoscopic kidney resection, indocyanine green, superselective $\mathrm{X}$-ray vascular embolization of the kidney.

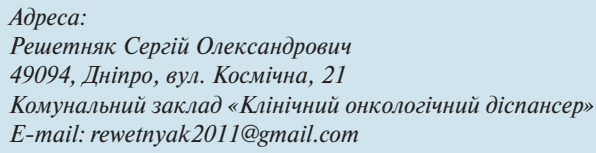

